\title{
VLA-5 Is Expressed by Mouse and Human Long-term Repopulating Hematopoietic Cells and Mediates Adhesion to Extracellular Matrix Protein Fibronectin
}

\author{
Johannes C.M. van der Loo, ${ }^{\star \S}$ Xiangli Xiao, ${ }^{\star}$ Doug McMillin, ${ }^{\star}$ Kimikazu Hashino, ${ }^{\ddagger}$ Ikunoshin Kato, ${ }^{\ddagger}$ and David A. Williams ${ }^{\star \S}$ \\ *Department of Pediatrics, Section of Hematology/Oncology, Herman B Wells Center for Pediatric Research, James Whitcomb Riley \\ Hospital for Children, Indiana University School of Medicine, Indianapolis, Indiana 46202; ${ }^{\ddagger}$ The Biotechnology Research Laboratories, \\ Takara Shuzo Co., Ltd., Otsu. Shiga, 520-21, Japan; and ${ }^{\S}$ Howard Hughes Medical Institute, Indiana University School of Medicine, \\ Indianapolis, Indiana 46202
}

\begin{abstract}
Fibronectin (FN), an extracellular matrix protein, is involved in the adhesion and migration of hematopoietic cells and has been shown to enhance retroviral gene transfer into primitive hematopoietic cells by co-localization of target cells and retrovirus when used as a substrate in vitro. We have previously found that mouse hematopoietic stem cells could be transduced on a FN fragment that included the recognition sequence Arg-Gly-Asp (RGD), suggesting that stem cells may express the integrin very late antigen (VLA)-5. To address this, we investigated the binding of mouse and human hematopoietic cells to recombinant peptides that contained one or a combination of the three principle cellbinding domains of FN. These domains included the VLA-5binding sequence RGD, the VLA-4-binding site CS1, and the high affinity heparin-binding domain. Here we show that mouse long-term in vivo repopulating stem cells, as well as primitive human NOD/SCID mouse repopulating cells, can bind extracellular matrix protein $\mathrm{FN}$ by using integrin VLA-5 in vitro. This binding is specific and can be inhibited by antibodies to VLA-5. In addition, preincubation of BM cells with peptide $\mathrm{CH}-296$, which contains all three primary FN-binding domains, decreased the engraftment of cells in the bone marrow in vivo, while intravenous injection of the same peptide induced an increase of progenitor cells in the spleen. In summary, our data demonstrate that VLA-5 is expressed on primitive mouse and human hematopoietic cells and suggest that there may be significant cooperation between integrin receptors and proteoglycan molecules in the engraftment of bone marrow cells and hematopoietic cell adhesion in vivo. (J. Clin. Invest. 1998. 102:1051-1061.) Key words: hematopoietic stem cells • fibronectin • VLA-5
\end{abstract}

\section{Introduction}

Hematopoiesis occurs in a complex environment in vivo, which includes not only cell-cell but also cell-matrix interac-

Address correspondence to David A. Williams, Howard Hughes Medical Institute, Indiana University School of Medicine, Indianapolis, IN 46202. Phone: 317-274-8960; FAX: 317-274-8679; E-mail: dwilliam @iupui.edu

Received for publication 10 April 1998 and accepted in revised form 30 June 1998.

J. Clin. Invest.

(C) The American Society for Clinical Investigation, Inc. 0021-9738/98/09/1051/11 \$2.00

Volume 102, Number 5, September 1998, 1051-1061

http://www.jci.org tions. For several decades, it has been appreciated that the survival of reconstituting hematopoietic stem cells in vitro depends to a large extent on the adhesion of these cells to stromal cells of the hematopoietic microenvironment (1). One of the molecules involved in the adhesion of hematopoietic cells is extracellular matrix protein fibronectin (FN; 2, 3). Recently, there has been a renewed interest in the adhesive properties of FN from the rapidly expanding field of gene therapy, as studies have shown that retroviral gene transfer into primitive hematopoietic cells could be increased by co-localization of retrovirus and target cells on specific FN domains (4-6). Interestingly, it has also become clear that the interaction of hematopoietic cells with FN may trigger intracellular signaling pathways that affect cell survival and proliferation (7-10). These findings may have important implications for the maintenance and manipulation of hematopoietic stem cells ex vivo.

The binding of hematopoietic cells to $\mathrm{FN}$ is mediated by a number of integrin receptors. The classical receptor is integrin $\alpha 5 \beta 1$ (CD49e/CD29: very late antigen [VLA]-5), which recognizes the minimal binding sequence Arg-Gly-Asp (RGD), as well as two other synergistic VLA-5 binding sites, all of which are located within the cell-binding domain of the FN molecule (11-14). A second well studied receptor is integrin $\alpha 4 \beta 1$ (CD49d/CD29: VLA-4), which binds sites within the alternatively spliced IIICS region of the molecule defined by the synthetic peptides CS1 and CS5 (15-17). In addition to these and other integrin receptors (18), the interaction between hematopoietic cells and FN also involves the cell surface complex of chondroitin-sulfate proteoglycan and CD44, which is recognized by the high-affinity $\mathrm{COOH}$-terminal heparin-binding domain of FN (as reviewed in 2,3).

VLA-4 has been demonstrated to play an important role in the interaction of primitive hematopoietic cells and the bone marrow (BM) extracellular matrix. For instance, mouse longterm repopulating hematopoietic stem cells (HSCs) have been shown to adhere to a chymotryptic fragment of FN (FN 30/35, which contains the heparin-binding site as well as the IIICS region) using VLA-4 (19). Human long-term culture-initiating cells have also been shown to adhere through VLA-4, as was demonstrated using a COOH-terminal chymotryptic/catheptic fragment of FN (20). In addition, intravenous injection of a VLA-4-specific antibody in vivo has been shown to mobilize progenitors from the BM into the blood in primates as well as

1. Abbreviations used in this paper: $\alpha$-MEM, $\alpha$-modification of Dulbecco's Modified Eagle's Medium; BM, bone marrow; FN, fibronectin; HEL, human erythroleukemia; HPP-CFC, high proliferative potential colony-forming cell; HSC, hematopoietic stem cell; IMDM, Iscove's Modified Dulbecco's Medium; SCF, stem cell factor; TBI, total body irradiation; VLA, very late antigen. 
in mice, while incubation of transplanted BM cells with antiVLA-4 antibody before transplantation significantly reduced their engraftment $(21,22)$.

In contrast, much less is known about the role of VLA-5 in the interaction of primitive hematopoietic cells with the extracellular matrix. In long-term BM cultures, binding of human hematopoietic cells to a peptide containing the VLA-5-binding site RGD has been shown to increase with differentiation (20). VLA-5 has also been shown to be differentially expressed during $\mathrm{T}$ cell differentiation $(23,24)$, in erythropoiesis $(25,26)$, and also in myelopoiesis (27). In vitro, it has been shown that some but not all primitive mouse hematopoietic cells could adhere to FN using VLA-5 (28). However, VLA-5 has not yet been demonstrated on primitive in vivo repopulating cells.

While studying FN-mediated retroviral gene transfer into mouse hematopoietic cells, we noted that the use of a peptide containing the VLA-5-binding sequence RGD appeared to be correlated with the transduction of long-term repopulating cells (6), suggesting that VLA-5 may be expressed by primitive hematopoietic cells. To investigate the potential role of VLA-5 in the binding of primitive hematopoietic cells to FN, we have used various well-defined and highly specific recombinant peptides, containing single domains or combinations of the three principal cell-binding domains of human plasma FN (29). Using cell adhesion assays and antibody blocking studies, we here demonstrate that VLA-5 is expressed on mouse HSC, as defined by long-term engraftment of adherent cells in WBB6F1/ $\mathrm{J}-\mathrm{Kit}^{\mathrm{W}} / \mathrm{Kit}^{\mathrm{W}-\mathrm{V}}$ animals, as well as on primitive human hematopoietic cells as shown by multilineage engraftment in immunodeficient NOD/SCID mice. In addition, we show that preincubation of cells with a recombinant peptide that contains both VLA-4- and VLA-5-binding sites as well as the heparin-binding domain reduced the engraftment of these cells to the marrow, while injection of this peptide induced a change in the distribution of hematopoietic progenitor cells in vivo.

\section{Methods}

Animals. Male and female C57BL/6J and WBB6F1/J-Kit ${ }^{\mathrm{W}} / \mathrm{Kit}^{\mathrm{W}-\mathrm{V}}$ animals, 8-16 wk old, were purchased from the Jackson Laboratory (Bar Harbor, ME) and maintained under conventional conditions at the Laboratory Animal Research Center at the Indiana University School of Medicine. B6.Hbb $/ H b b^{\mathrm{d}}, G p i-1^{a} / G p i-1^{a}$ animals were kindly provided by Dr. M.C. Yoder (Indiana University). A breeding colony of NOD/LtSz-scid/scid (NOD/SCID) mice (30) was established using breeding pairs kindly provided by Dr. L.D. Shultz (Jackson Laboratory). NOD/SCID animals were housed in a positive airflow ventilated rack (Lab Products, Maywood, NJ) and bred and maintained in microisolators under specific pathogen-free conditions. All mice received autoclaved food and acidified water ad libitum. Before transplantation, NOD/SCID mice received $300 \mathrm{cGy}$ total body irradiation (TBI) at $86 \mathrm{cGy} / \mathrm{min}$ using a GammaCell 40 (Nordion International Inc., Ontario, Canada) equipped with two opposing ${ }^{137}$ Cesium sources. In specific experiments, C57BL/6J mice received a single dose of 920 cGy (TBI). All animal experiments were performed in accordance with institutional guidelines approved by the Animal Care Committee of the Indiana University School of Medicine.

Mouse bone marrow cells. Mouse BM cells were harvested by flushing the femurs with HBBS (GIBCO BRL, Grand Island, NY) containing $25 \mathrm{mMol} / \mathrm{L}$ HEPES (GIBCO BRL), 0.1\% (wt/vol) BSA (Boehringer Mannheim, Indianapolis, IN), $100 \mathrm{U} / \mathrm{mL}$ penicillin, and $100 \mu \mathrm{g} / \mathrm{mL}$ streptomycin (2\% Pen/Strep; GIBCO BRL). Mononuclear cells were isolated by buoyant density centrifugation $(700 \times g$ for $30 \mathrm{~min}$ at $25^{\circ} \mathrm{C}$ ) using Histopaque-1083 (Sigma, St. Louis, MO).
Cells were then washed and resuspended in $\alpha$-MEM ( $\alpha$-modification of Dulbecco's modified Eagle's medium; GIBCO), containing 10\% FCS (Introgen, Purchase, NY) and 2\% Pen/Strep.

Human cells. Human BM and peripheral blood cells were collected from healthy consenting adult human volunteers according to protocols approved by the Institutional Review Board of the Indiana University School of Medicine. BM cells were washed and diluted in Iscove's Modified Dulbecco's Medium (IMDM) containing 10\% FCS, $2 \%$ Pen/Strep, and $20 \mathrm{U} / \mathrm{mL}$ heparin and low density mononuclear cells $(<1.077 \mathrm{~g} / \mathrm{mL})$ were isolated by centrifugation $(700 \mathrm{~g}$, for $30 \mathrm{~min}$ at $25^{\circ} \mathrm{C}$ ) on Ficoll-Hypaque (Pharmacia LKB Biotechnology Inc., Piscataway, NJ). BM CD34+ cells were isolated using the Magnetic Activated Cell Sorter (Miltenyi Biotec, Auburn, CA) according to the manufacturer's instructions. Human peripheral blood cells were collected by apheresis after $5 \mathrm{~d}$ of administration of human granulocyte colony-stimulating factor (G-CSF; Filgrastim Neupogen $^{\circledR}$, Amgen [Thousand Oaks, CA]; at $10 \mu \mathrm{g} / \mathrm{kg} /$ day) and CD34 ${ }^{+}$ cells were isolated by immunomagnetic methods using the Isolex ${ }^{\circledR}$ 300 i cell selection device (Baxter Immunotherapy, Irvine, CA). For these studies, cell selection kits and disposables were kindly provided by Baxter Immunotherapy. In specific experiments, magnetically selected $\mathrm{CD}_{4}{ }^{+}$cells were labeled with CD34-FITC and CD38-PE (both from Becton Dickinson, Mountain View, CA) and CD $34^{+} 38^{-}$ cells (representing $10 \%$ of all CD $34^{+}$cells) were sorted on a FACStar Plus flow cytometer (Becton Dickinson).

Coating of FN peptides. Recombinant human FN fragments were expressed in Escherichia coli and purified as previously described (29). Nontissue culture 96-well plates were coated with FN fragments diluted in PBS at $0.4-200 \mathrm{nmol} / \mathrm{cm}^{2}$ (4 wells/concentration) for 2-4 h at room temperature. To block nonspecific binding sites, plates were subsequently incubated for $30 \mathrm{~min}$ with a $2 \%$ (wt/vol) solution of BSA in PBS. Wells were then washed three times with $200 \mu \mathrm{L}$ PBS, $0.1 \%$ (vol/vol) Tween-20 (Sigma) and incubated for $30 \mathrm{~min}$ at $37^{\circ} \mathrm{C}$ with mouse antibodies specific for the heparin-binding domain (FNH3-8; Takara Shuzo, Otsu, Japan) and cell-binding domain (FN12-8; Takara Shuzo) of FN (31). Antibodies were used at a previously determined optimal dilution in PBS, $0.1 \%$ Tween-20, and $0.1 \%$ (wt/vol) BSA. After incubation, plates were washed with washing buffer and incubated for $30 \mathrm{~min}$ at $37^{\circ} \mathrm{C}$ with horseradish peroxidaseconjugated goat anti-mouse IgG (GIBCO BRL). After washing again, wells were incubated with $100 \mu \mathrm{L}$ peroxidase substrate solution (1-Step Turbo TMB-ELISA; Pierce, Rockford, IL) for $15 \mathrm{~min}$ at room temperature. The reaction was stopped with $100 \mu \mathrm{L}$ of $1 \mathrm{~mol} / \mathrm{L}$ $\mathrm{H}_{2} \mathrm{SO}_{4}$ and the optical density was measured at $450 \mathrm{~nm}$ using an ELISA reader (Molecular Devices, Menlo Park, CA).

Cell adhesion assays. Nontissue culture plates were coated with FN fragments at $100 \mathrm{nmol} / \mathrm{cm}^{2}$ for 2-4 h and blocked with BSA as described above. Before FN adherence, mouse and human hematopoietic cells were depleted of plastic-adherent cells by a short 30 -min incubation in tissue culture plates at $37^{\circ} \mathrm{C}$. Nonadherent cells were then allowed to adhere to the $\mathrm{FN}$-coated plates for $1 \mathrm{~h}$ at $37^{\circ} \mathrm{C}$ at $2 \times 10^{6}$ cells/well in $35-\mathrm{mm}$ petri dishes or $15-20 \times 10^{6}$ cells in $10-\mathrm{cm}$ petri dishes in $\alpha$-MEM or IMDM tissue culture medium containing $10 \%$ FCS and 2\% Pen/Strep. In specific experiments, cells were preincubated for $30 \mathrm{~min}$ at $4^{\circ} \mathrm{C}$ with $10 \mu \mathrm{g} / \mathrm{mL}$ human or mouse integrin-specific blocking antibody, isotype control antibody, or $500 \mu \mathrm{g} / \mathrm{mL}$ heparin (high molecular weight heparin sodium salt; Sigma), and allowed to adhere to $\mathrm{FN}$-coated plates in the presence of antibody or heparin. Antibodies against mouse VLA-4 (anti-CD49d, clone R1-2, rat IgG2b and 9C10 [MFR4.B] rat IgG2a), mouse VLA-5 (anti-CD49e, clone 5H10-27 [MFR5], rat IgG2a), human VLA-5 (anti-CD49e, clone IIA1, mouse IgG1), as well as isotype control rat IgG2a (clone R35-95), rat IgG2b (R35-38), and mouse IgG1 (anti-TNP, clone 107.3) were purchased from PharMingen (San Diego, CA). All antibodies were unconjugated and contained no sodium azide. After incubation, nonadherent cells were collected by carefully rinsing the plates multiple times with medium. Adherent cells were harvested by vigorously rinsing the plates with PBS, followed by a 1-2-min 


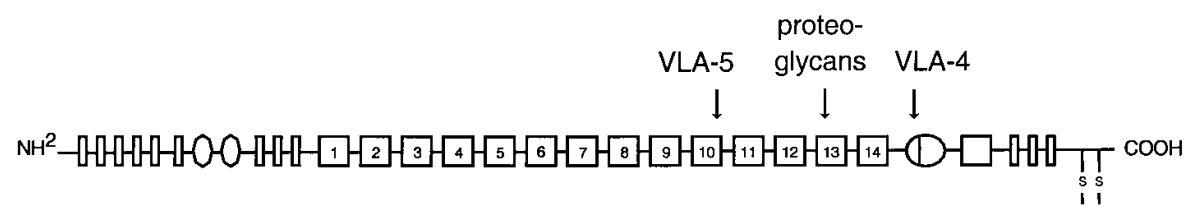

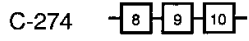

$\begin{array}{cc}\text { Type I } & \square \\ \text { Type II } & 0 \\ \text { Type III } & \square\end{array}$
$\mathrm{H}-271$

$\mathrm{H}-296$

$\mathrm{CH}-271$

$\mathrm{CH}-296$

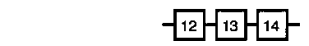

$-12-13-14-0$

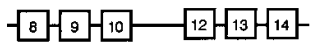

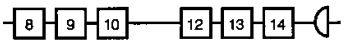

Figure 1. FN and FN peptides. Schematic representation of the A chain of a FN dimer and the corresponding domains present in E. coli-produced recombinant FN fragments (29). The designations of the recombinant $\mathrm{FN}$ fragments are shown next to schematic drawings of each fragment. Indicated are the types I, II, and III homologous sequence repeats as well as the cell binding site (CELL), which contains the Arg-Gly-Asp (RGD) cell adhesion recognition sequence that is recognized by VLA-5, the high-affinity heparin binding site $(H E P)$, and the alternatively spliced non-type III connecting segment (III CS) that contains the VLA-4-specific cell-binding site as represented by peptide CS-1. trypsinization at $37^{\circ} \mathrm{C}$. Remaining cells were finally removed from the plates using a cell scraper (Fisher Scientific, Pittsburgh, PA).

Cell lines. Murine lymphocytic leukemia L1210 cells (32), murine myeloid leukemia M1 cells (33), and human erythroleukemia (HEL) cells (34) were obtained from the American Type Culture Collection (Rockville, MD). L1210 cells were cultured in RPMI 1630 (GIBCO BRL), $15 \%$ calf serum, $2 \%$ Pen/Strep, $2 \mathrm{mM}$ L-glutamine, while M1 and HEL cells were cultured RPMI 1640, 10\% FCS, 2\% Pen/Strep.

Mouse HPP-CFC assay. High proliferative potential colonyforming cells (HPP-CFC) were enumerated in a standard doublelayer agar culture system as previously described (35). In brief, a $1 \%$ and $0.6 \%(\mathrm{wt} / \mathrm{vol})$ solution of warm agar (Difco, Detroit, MI) in distilled water was mixed with an equal volume of double-strength $\alpha$-MEM tissue culture medium. The agar medium also contained $2 \mathrm{mMol} / \mathrm{L}$ L-glutamine, $20 \% \mathrm{FCS}$, and $2 \%$ Pen/Strep (at final concentrations). The $0.5 \%$ bottom agar was plated at $1 \mathrm{~mL} /$ dish in $35-\mathrm{mm}$ gridded tissue culture dishes (Sarstedt, Newton, NC) containing 100 $\mathrm{ng} / \mathrm{mL}$ recombinant rat stem cell factor (SCF; Amgen), $200 \mathrm{U} / \mathrm{mL}$ recombinant murine IL-3 (Peprotech, Rocky Hill, NJ), 1,000 U/mL recombinant murine IL-1 $\alpha$ (Genzyme, Boston, MA), and 1,600 U/mL recombinant human macrophage colony-stimulating factor (Genetics Institute, Boston, MA). Using triplicate plates, mouse BM cells were cultured in the $0.3 \%$ top agar (at $1 \mathrm{~mL} /$ dish in $35-\mathrm{mm}$ gridded tissue culture dish) at $37^{\circ} \mathrm{C}$ in a humidified environment at $5 \% \mathrm{O}_{2}, 10 \%$ $\mathrm{CO}_{2}$. After $14 \mathrm{~d}$, HPP-CFC colonies were morphologically identified as compact and dense colonies with a diameter of $>0.5 \mathrm{~mm}$.

Progenitor assays. Human progenitor cells were cultured in $1 \mathrm{~mL}$ of semisolid tissue culture medium consisting of IMDM (GIBCO BRL), $25 \%$ FCS, $10 \%$ human plasma, $2 \%$ Pen $/$ Strep, $5 \times 10^{-5} \mathrm{~mol} / \mathrm{L}$ $\beta$-mercapto-ethanol, $11 \mathrm{ng} / \mathrm{mL}$ human IL-3 (Peprotech), $100 \mathrm{ng} / \mathrm{mL}$ human SCF (Amgen), $4 \mathrm{U} / \mathrm{mL}$ human erythropoietin (Amgen) and $0.8 \%$ methylcellulose (Stem Cell Technologies, Vancouver, BC, Canada). Mouse progenitor cells were cultures in triplicate in $\alpha$-MEM, $30 \%$ FCS, $2 \%$ Pen/Strep, 2 mMol/L L-glutamine (GIBCO BRL), $1 \times$ $10^{-4} \mathrm{~mol} / \mathrm{L} \beta$-mercapto-ethanol, $100 \mathrm{U} / \mathrm{mL}$ recombinant mouse IL-3 (Peprotech), $100 \mathrm{ng} / \mathrm{mL}$ recombinant rat SCF (Amgen), $4 \mathrm{U} / \mathrm{mL}$ recombinant human erythropoietin and $0.8 \%$ methylcellulose (Stem Cell Technologies). Colonies were counted after $14 \mathrm{~d}$ of culture in a humidified environment at $37^{\circ} \mathrm{C}$ and $5 \% \mathrm{CO}_{2}$.

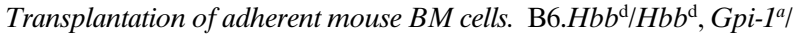
$G p i-1^{a}$ mouse low density BM cells were allowed to adhere to BSAcoated or FN-coated plates, in the presence or absence of anti-mouse VLA-5 blocking antibody (anti-CD49e, clone 5H10-27 (MFR5); PharMingen) or isotype control (rat IgG2a) antibody. After removing the nonadherent cells, various proportions of the adherent cells were transplanted into groups of nonirradiated WBB6F1/J-Kit ${ }^{\mathrm{W}} / \mathrm{Kit}{ }^{\mathrm{W}-\mathrm{V}}$ $\left(H b^{d} / H b^{s}\right)$ mice (five mice/group) by lateral tail vein injection. At 3-6 mo after transplantation, peripheral blood hematopoietic chimerism was determined by hemoglobin electrophoresis as has previously been described (36).

Transplantation of adherent human $\mathrm{CD}_{3} 4^{+}$cells in NOD/SCID mice. Human peripheral blood $\mathrm{CD} 34^{+}$cells were allowed to adhere to BSA-coated or FN-coated 10-cm petri dishes at $15-20 \times 10^{6}$ cells/
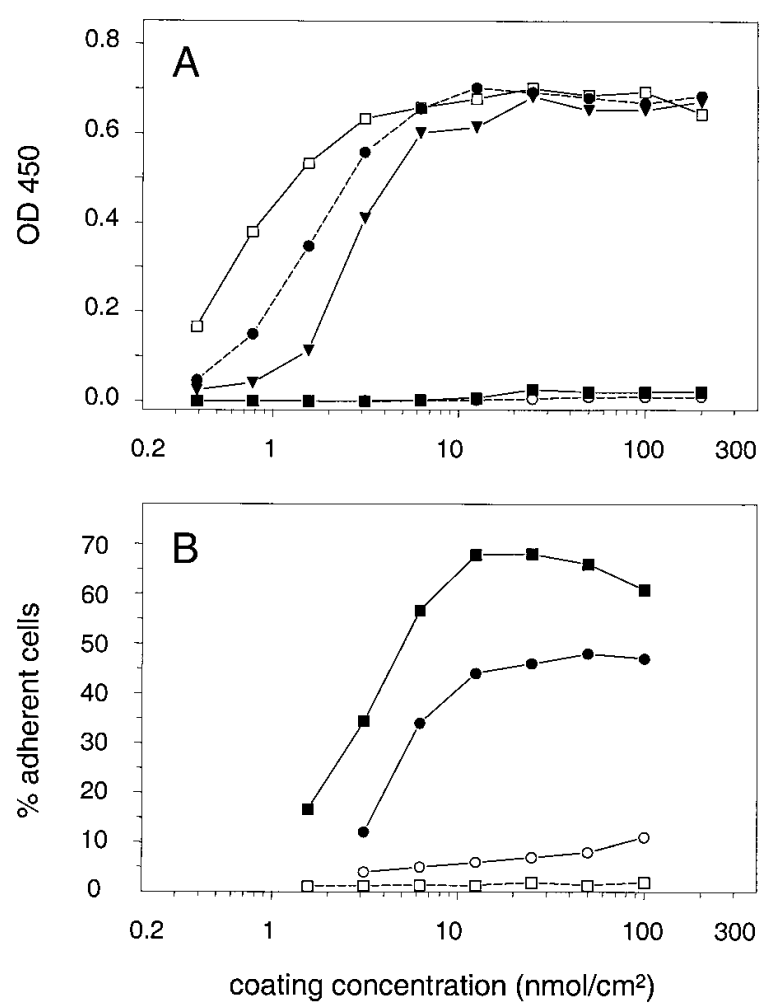

Figure 2. Plastic adherence of FN peptides. Effect of the coating concentration on the adsorption of recombinant $\mathrm{FN}$ fragments to nontissue culture-treated plastic $(A)$ and on the subsequent binding of mouse BM cells or human HEL cells $(B)$. Bound FN was detected by ELISA (average of 4 wells/concentration) using antibody FN12-8 $(A)$, which is specific for the CELL-binding domain of FN. $(A)$ Fragment $\mathrm{H}-271$ (filled squares), C-274 (open squares), $\mathrm{CH}-271$ (filled circles), H-296 (open circles), and CH-296 (filled triangles). For clarity, error bars have been omitted. $(B)$ Binding of human HEL cells (squares) or low-density mouse BM cells (circles) to plates coated with H-271 (open symbols) or CH-296 (closed symbols). 
dish. Adhesion to plates coated with peptide C-274, which contains the recognition sequence RGD, was performed in the presence of either anti-human VLA-5 antibody (anti-CD49e, clone IIA1; PharMingen) or isotype control (mouse IgG1) antibody. In these specific experiments the tissue culture medium was supplemented with 100 $\mathrm{ng} / \mathrm{mL}$ human SCF and $100 \mathrm{U} / \mathrm{mL}$ human IL-6, conforming to the protocol we have used previously for gene transfer (6). After $1 \mathrm{~h}$, nonadherent cells were removed and adherent cells were collected and transplanted into NOD/SCID mice preirradiated with $300 \mathrm{cGy}$ TBI. After 8 wk, human-mouse hematopoietic chimerism was determined by FACScan analysis (Becton Dickinson) using anti-CD45 human leukocyte-specific and anti-mouse CD18 monoclonal antibodies. Human B cells and myeloid cells were detected using antibodies specific for CD19, CD33, and HLA-DR (all from Becton Dickinson).

Effect of FN peptides on engraftment. To measure the ability of FN peptides or anti-integrin antibodies to interfere with the marrow repopulating ability (MRA [37]) of mouse low-density mouse BM cells, cells were preincubated for $30 \mathrm{~min}$ at $4^{\circ} \mathrm{C}$ with recombinant $\mathrm{FN}$ fragments, or with anti-VLA-4/CD49d (clones R1-2 and 9C10 [MFR4.B]; PharMingen), anti-VLA-5/CD49e (clone 5H10-27 [MFR5]; PharMingen), a combination of both or isotype control antibodies (all at a saturating concentration of $100 \mu \mathrm{g} / \mathrm{mL}$ ). Cells were then washed and intravenously injected into irradiated (920 cGy TBI) splenectomized C57BL/6J mice (4 mice/group). Animals had been splenectomized to exclude a possible effect of changes in spleen seeding on the BM engraftment. $10 \mathrm{~d}$ after transplantation mice were sacrificed, femoral BM was collected, pooled per group and tested for in vitro colonyforming cells in methylcellulose cultures.

Intravenous injection of $F N$ fragments. To study the effect of FN peptides on the distribution of hematopoietic progenitor cells in vivo, C57BL/6J mice were intravenously injected for $1-4$ consecutive days with various amounts of low endotoxin (0.1-0.8 USP EU/mg) recombinant FN fragments, ranging from 0.5 to $7.5 \mathrm{mg} / \mathrm{kg} / \mathrm{day}$, in HBBS, 25
$\mathrm{mMol} / \mathrm{L}$ HEPES, $0.1 \%$ BSA. Controls included vehicle alone or human recombinant G-CSF (Filgrastim Neupogen ${ }^{\circledR}$, at $250 \mu \mathrm{g} / \mathrm{kg} / \mathrm{day}$; Amgen). All injections were given once daily and animals were sacrificed $\sim 4 \mathrm{~h}$ after the last injection. A single-cell suspension of spleen cells was prepared by gently rubbing the spleen over a nylon $100-\mu \mathrm{m}$ mesh filter. Cells were washed in PBS and erythrocytes were lysed during a 2-min incubation at $4^{\circ} \mathrm{C}$ in $155 \mathrm{mMol} / \mathrm{L} \mathrm{NH}_{4} \mathrm{Cl}, 10 \mathrm{mMol} / \mathrm{L}$ $\mathrm{KHCO}_{3}, 0.1 \mathrm{mMol} / \mathrm{L}$ EDTA (all from Sigma) at $\mathrm{pH}$ 7.4. The number of HPP-CFC in BM and spleen were enumerated in agar cultures as described above.

Statistical analyses. Differences between groups were compared by Student's $t$ test, ANOVA, or by using the nonparametric Wilcoxon test or Kruskal-Wallis test. Differences were considered significant at $P<0.05$.

\section{Results}

Plastic adherence of recombinant peptides. To quantify the binding of recombinant $\mathrm{FN}$ fragments (Fig. 1) to nontissue culture-treated plastic, plates were coated with equimolar amounts of peptide and tested by ELISA. The antibodies used were specific for the cell-binding domain (FN12-8; Fig. $2 \mathrm{~A}$ ) and high-affinity HEP-binding domain (FNH3-8; not shown) of FN. For all peptides, the plastic adsorption reached a plateau at a concentration of $10-20 \mathrm{nmol} / \mathrm{cm}^{2}$. As expected, fragments lacking the cell-binding domain (i.e., H-271 and H-296) were not detected by antibody FN12-8 (Fig. $2 A$ ), while the fragment that lacked the type III repeats 12-14 (i.e., C-274) was not detected by antibody FNH3-8 (not shown). The adhesion of human HEL cells or mouse low-density BM cells to fragment $\mathrm{CH}-296$ reached a maximum at a similar coating con-
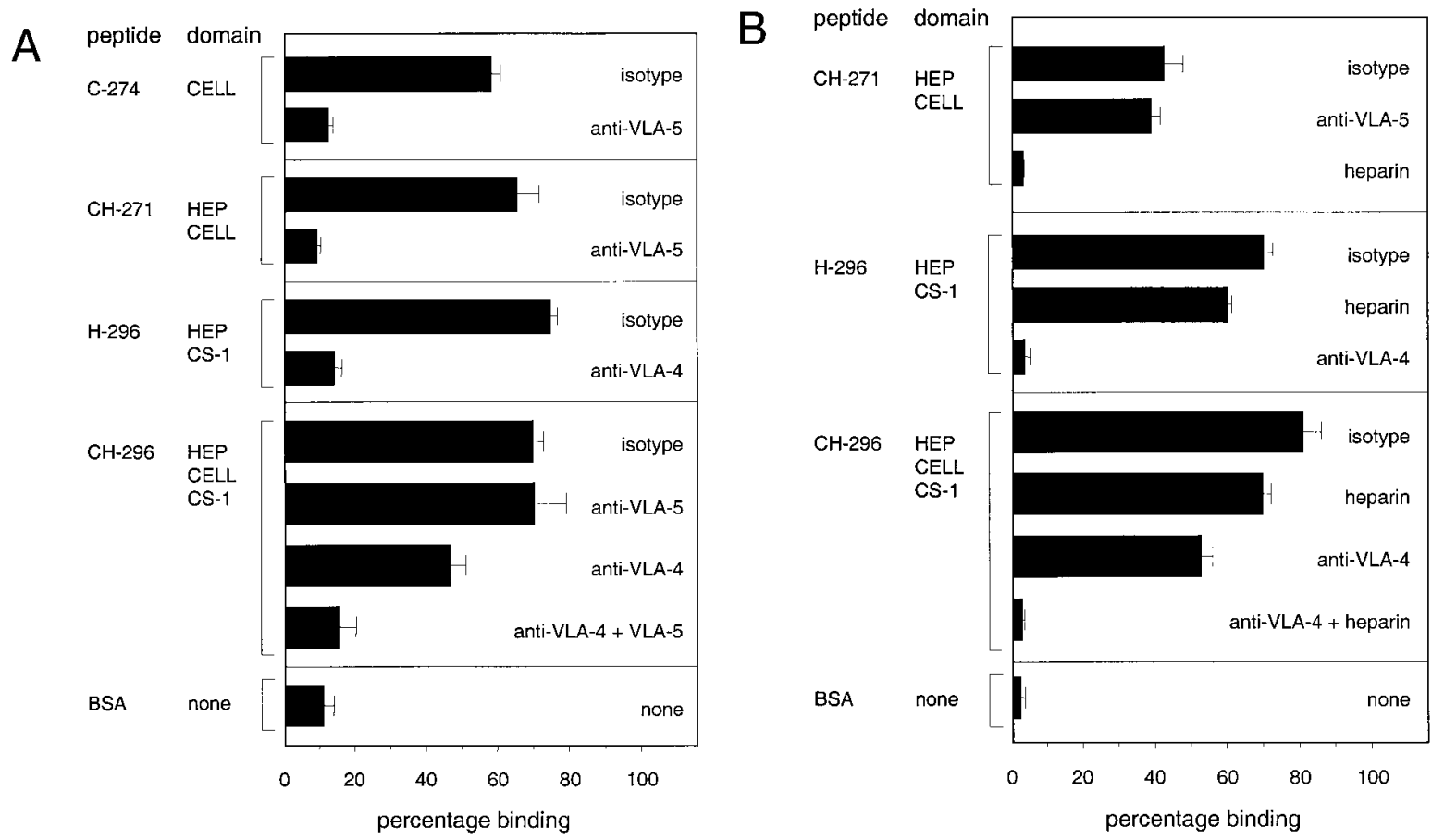

Figure 3. Characterization of FN fragments. Binding of murine M1 $(A)$ or L1210 $(B)$ leukemia cells to nontissue culture-treated 24-well plates coated with recombinant FN fragments (at $100 \mathrm{nmol} / \mathrm{cm}^{2}$ ) in the presence of anti-VLA4 (CD49d, clones R1-2 and 9C10 [MFR4.B]) or antiVLA-5 (CD49e, clone 5H10-27 [MFR5]) blocking antibodies, isotype control antibodies (all at $10 \mu \mathrm{g} / \mathrm{mL}$ ) or heparin (at $500 \mu \mathrm{g} / \mathrm{mL}$ ). M1 express both VLA-4 and VLA-5 while L1210 cells only express VLA-4 (not shown). Cells were preincubated for $30 \mathrm{~min}$ at $4^{\circ} \mathrm{C}$ and then allowed to bind to the FN-coated plates in the presence of antibody or heparin. After $1 \mathrm{~h}$ incubation at $37^{\circ} \mathrm{C}$, nonadherent cells were washed away and the number of adherent cells was determined by Coulter counter. Bars indicate average \pm SD of four wells. 
centration (Fig. 2 B). In contrast, fragment H-271, which lacks the CS-1- and CELL-binding domains but contains the heparin-binding domain, showed only a very low cell-binding activity. Based on these results, a coating concentration of 100 $\mathrm{nmol} / \mathrm{cm}^{2}$ was chosen for all subsequent binding studies. A time-course experiment at this concentration showed that $85 \%$ of the peptides that can be bound over a period of $4 \mathrm{~h}$ are already adsorbed to the plastic within the first $10 \mathrm{~min}$ (data not shown).

Functionality of FN peptide cell-binding domains. Next, we tested whether the various recombinant FN peptides were able to bind hematopoietic cells through their specific cell-binding domains. Plates were coated with recombinant $\mathrm{FN}$ peptides at $100 \mathrm{nmol} / \mathrm{cm}^{2}$, and M1 mouse leukemia cells were allowed to adhere to these peptides in the presence or absence of blocking anti-VLA-4 and/or anti-VLA-5 antibody, isotype control antibody, or heparin. The binding of M1 cells to various FN peptides could specifically be blocked by anti-VLA-4 and/or anti-VLA-5 antibodies (Fig. $3 \mathrm{~A}$ ), indicating that all recombinant peptides used in our study contained functional VLA-4(CS-1) and VLA-5- (CELL) binding domains. Although, M1 cells did not adhere to the HEP-binding domain of any peptide, binding to this domain could be demonstrated using mouse leukemia cell line L1210 (Fig. 3 B). As these cells do not express VLA-5 (not shown), binding to peptide CH-271 (HEP + CELL) could be completely blocked by heparin. Similarly, binding to CH-296 (HEP + CELL + CS-1) could be inhibited by heparin and anti-VLA-4. Surprisingly, binding of L1210 to peptide H-296 (HEP + CS-1) could be blocked by anti-VLA-4, while the addition of heparin hardly affected the binding (Fig. $3 \mathrm{~B}$ ). This suggests that the HEP-binding domain in peptide $\mathrm{H}-296$ did not substantially contribute to cell binding. Similarly, the HEP-binding domain in peptide $\mathrm{H}-271$ was also less active, binding M1 and L1210 cells at only baseline levels (5-12\%; not shown). These differences in the activity of the HEP-binding domain between peptides $\mathrm{H}-271$ and $\mathrm{CH}-271$ and $\mathrm{H}-296$ and $\mathrm{CH}-296$, may reflect differences in the tertiary structure imposed on this domain by the inclusion of the CELL-binding domain in CH-271 and CH-296.

Binding of mouse and human low density bone marrow cells and progenitors. Mouse and human progenitor cells (Fig. $4, A$ and $B$, respectively) and mouse and human low-density cells (not shown) bound similarly to recombinant FN peptides. The results show a low level of adhesion to peptide H-271 (HEP), an intermediate level of adhesion to peptides C-274 (CELL) and CH-271 (HEP + CELL), and maximum adhesion to peptides H-296 (HEP + CS-1) and CH-296 (HEP + CELL + CS-1). For mouse as well as human cells and progenitors (Fig. 4, $A$ and $B$ ), no significant difference could be found between the binding to peptide CH-296 (HEP + CELL + CS-1) and H-296 (HEP + CS-1). In addition, a measurable population of mouse as well as human progenitor cells did bind to C-274, a peptide containing the RGD sequence but lacking the CS-1or HEP-binding sites. These results suggest that the interaction of mouse and human hematopoietic progenitor cells with extracellular matrix protein $\mathrm{FN}$ in vitro are dominated by integrin receptor VLA-4, while some cells clearly adhere to RGD-containing peptide C-274.

Adherence of mouse hematopoietic stem cells. To test the adherent properties of more primitive mouse hematopoietic cells, we injected a fixed proportion of FN peptide-adherent low density B6.Hbb $b^{\mathrm{d}} / H b b^{\mathrm{d}}, G p i-1^{a} / G p i-1^{a}$ BM cells into groups of nonirradiated $\mathrm{WBB} 6 \mathrm{~F} 1 / \mathrm{J}-\mathrm{Kit}^{\mathrm{W}} / \mathrm{Kit}^{\mathrm{W}-\mathrm{v}}, H b b^{\mathrm{s}} / H b b^{\mathrm{d}}$ mice. Hematopoietic chimerism was determined by hemoglobin electrophoresis at 6 mo after transplantation (Fig. 5). In Fig. 5, the lanes marked $D$ and $R$ represent hemoglobin bands from donor and untransplanted recipient animals, respectively. The electrophoretic pattern demonstrated that a low number of stem cells was contained in the BSA-adherent fraction, with donor-type hemoglobin detected in only one out of nine animals (lane 8). In contrast, all animals transplanted with C274adherent BM cells showed a complete conversion to donortype hemoglobin (on average $99.5 \%$, as detected by densitometry; Fig. $5 \mathrm{~B}$ ), indicating that engrafting HSCs were present among the population of cells adherent to RGD-containing peptide C-274. The engraftment was comparable with the engraftment in animals transplanted with $\mathrm{CH}-296$ adherent BM
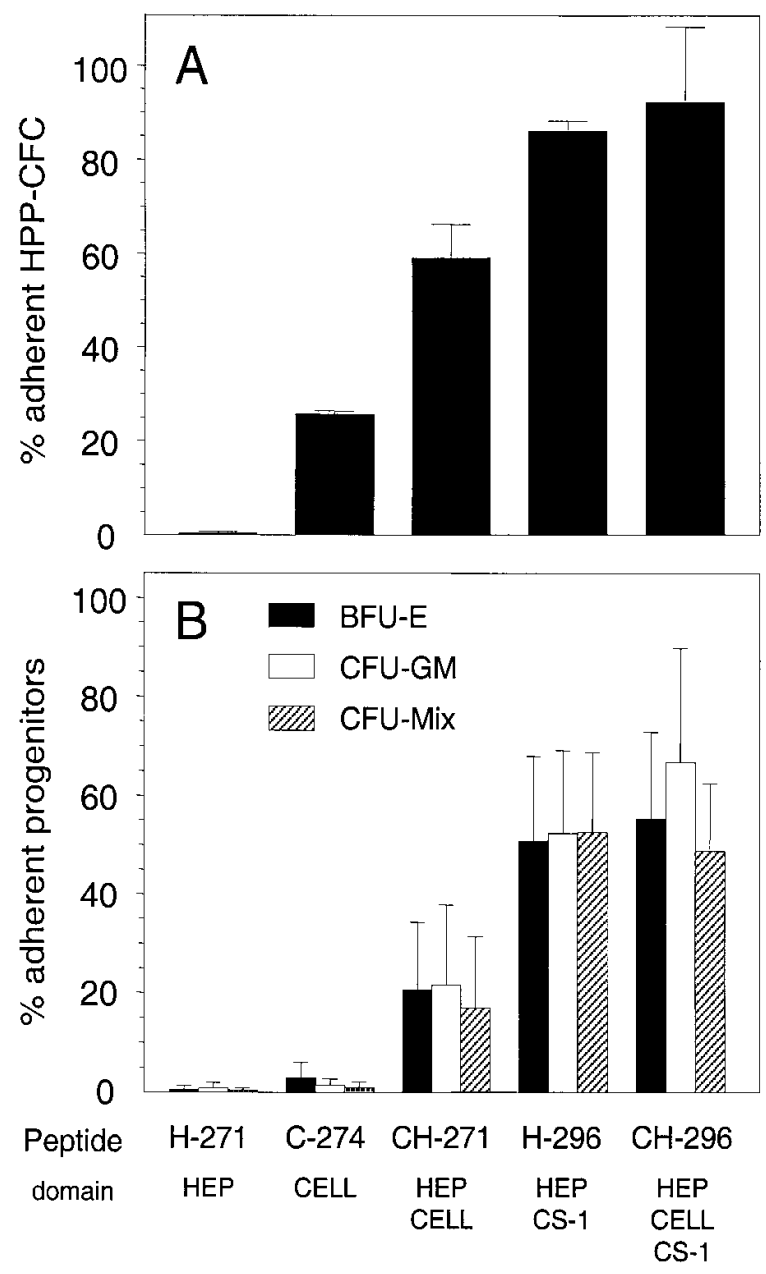

Figure 4. Adhesion of mouse and human clonogenic cells. Binding of $(A)$ mouse and $(B)$ human clonogenic cells from low-density BM cells to nontissue culture $35-\mathrm{mm}$ plates coated with $100 \mathrm{nmol} / \mathrm{cm}^{2}$ recombinant FN fragments. Cells $\left(2 \times 10^{6}\right.$ cells per plate $)$ were allowed to adhere for $1 \mathrm{~h}$ at $37^{\circ} \mathrm{C}$ as described in Methods. After removing all nonadherent cells, adherent cells were tested for HPP-CFC (mouse) and BFU-E, CFU-GM, and CFU-Mix (human) using standard clonogenic assays. The different FN peptides, as well as their respective binding domains, are indicated in the graph. Bars denote the average percentage of adherent cells $( \pm$ SD) of four experiments (after subtraction of the number of progenitors adherent to BSA-coated control plates). All differences are significant $(P<0.001)$ except between $\mathrm{H}-271$ and C-274 $(B)$ and H-296 and CH-296 ( $A$ and $B)$. 


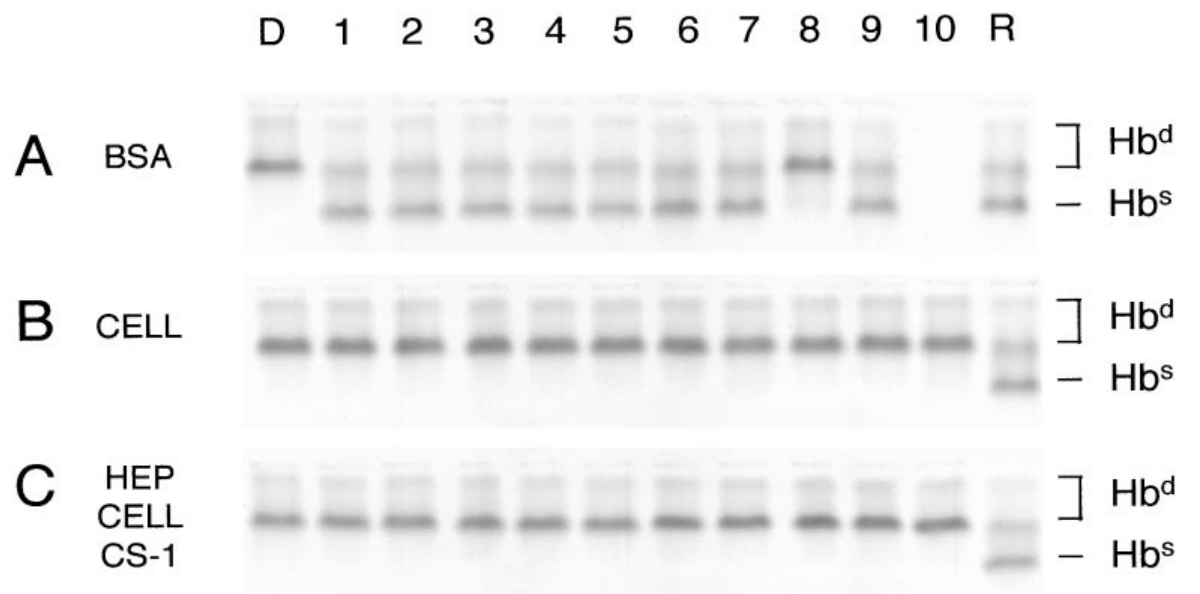

Figure 5. Long-term engraftment of adherent cells. Hemoglobin electrophoresis of $\mathrm{RBC}$ lysate from WBB6F1/J-Kit ${ }^{\mathrm{W}} / \mathrm{Kit}^{\mathrm{W}-\mathrm{V}}$ animals transplanted with BSA-adherent or $\mathrm{FN}$-adherent $\mathrm{BM}$ cells from $\mathrm{B} 6 . H b b^{\mathrm{d}}$ / $H b b^{\mathrm{d}}, \mathrm{Gpi-1}{ }^{a} / \mathrm{Gpi}-1^{a}$ animals, at 6 mo posttransplantation. Animals in each group received a fixed proportion of the total number of cells adherent to each of the peptides. In this experiment, each animal received the adherent fraction from a total of $7 \times 10^{5}$ to $1 \times 10^{6}$ low-density cells.

Shown are animals transplanted with cells adherent to $(A) B S A,(B)$ fragment C-274 $(C E L L)$, and $(C)$ fragment CH-296 (HEP + $C E L L+C S-1)$. Each gel includes a control lane with donor hemoglobin (homozygous $H b^{\mathrm{d}} / H b^{\mathrm{d}}$, indicated with $\left.D\right)$ and untransplanted recipient (heterozygous $H b^{\mathrm{d}} / H b^{\mathrm{s}}$, indicated with $R$ ). Chimerism was quantified by densitometry. cells (Fig. $5 \mathrm{C}$ ). These results demonstrate that long-term repopulating stem cells adhere to an FN fragment that contains RGD but not CS1, suggesting that these cells express integrin VLA-5.

Specificity of VLA-5 in adherence of mouse progenitors and long-term repopulating cells. To prove that the interaction of mouse hematopoietic cells and FN peptide C-274 was mediated by VLA-5, we repeated our binding studies in the presence of either an isotype control antibody or anti-mouse VLA-5 blocking antibody (Fig. 6). The addition of anti-VLA-5 significantly reduced the number of low-density cells (Fig. $6 \mathrm{~A}$, $P<0.05$ ) and HPP-CFC (Fig. $6 B, P<0.005$ ) that bound to peptide C-274. Similarly, after transplantation of a fixed proportion of the C-274-adherent cells from plates incubated with anti-VLA-5 antibody (Fig. 6, $C$ and $D$, representing a high and a threefold lower fraction of adherent cells injected, respectively), there was a significant decrease in the average level of donor-type hemoglobin when compared with control $(P=$ 0.0017). Based on the mean engraftment level in control groups in Fig. 6, $C$ and $D(89.4$ and $47.5 \%$, respectively, of which the cell doses are threefold apart), and lower level of engraftment with anti-VLA-5 (66.4\% in Fig. 6 C), it can be estimated by extrapolation that $\sim 50 \%$ of the binding to fragment C-274 is mediated by VLA-5. Furthermore, injection of $20 \%$ of the nonadherent fraction from the VLA-5-treated plates (from Fig. $6 C$ ) induced a chimerism of $75.9 \pm 10 \%$ (mean \pm SEM; $n=5$; data not shown). When compared with the abovementioned engraftment levels and specificity of binding, the data indicate that $10-15 \%$ of mouse HSCs are capable of adhering to peptide C-274 using VLA-5. Together, these results support the conclusion that VLA-5 is involved in the adhesion of mouse hematopoietic progenitors as well as long-term repopulating stem cells to extracellular matrix protein $\mathrm{FN}$ in vitro.

Role of VLA-5 in adherence of human hematopoietic cells to $F N$. Similar to the studies with mouse hematopoietic cells, binding studies with human $\mathrm{CD}^{+} 4^{+}$cells were performed in the presence or absence of anti-VLA-5 monoclonal antibody. Primitive human hematopoietic cells were measured by intravenous injection of adherent cells into sublethally irradiated immunodeficient NOD/SCID mice, as previously described
(38). To generate enough cells for transplantation, $\mathrm{CD} 34^{+}$cells were purified from G-CSF mobilized peripheral blood apheresis products. We have recently shown high-level and multilineage engraftment from such products in NOD/SCID mice (38). CD $34^{+}$cells were found to adhere to BSA-coated plates at a low level, while $\sim 30 \%$ of the cells adhered to peptide C-274, and $95 \%$ of the cells adhered to CH-296 (Fig. $7 A$ ). Incubation with anti-VLA-5 monoclonal antibody reduced the binding of cells to peptide C-274 (Fig. $7 A$ ). The reduction in BFU-E, CFU-GM, CFU-Mix (Fig. $7 B$; for all $P<0.001$ ), and NOD/SCID-repopulating cells (Fig. $7 C, P=0.02$ and Fig. 8, $C-F$ ) was statistically significant. In contrast with the difference in binding of CD34 ${ }^{+}$cells to peptides $\mathrm{CH}-296$ and C-274 (Fig. $7 A, P<0.0001$ ), no statistical difference was found between the binding of NOD/SCID-repopulating cells to peptides $\mathrm{CH}-296$ and $\mathrm{C}-274$ (Fig. $7 C, P=0.3$ ) suggesting that the majority of these cells express VLA-5. This conclusion was also supported by the finding that injection of the nonadherent cells from the anti-VLA-5-treated plate induced a $41.9 \pm 0.8 \%$ (mean \pm SEM, $n=2$ ) engraftment, which is similar to the $32.3 \pm 13.4 \%$ (mean \pm SEM, $n=2 ; P=0.55$ ) engraftment induced by the adherent cells from the isotype-treated plate. In all engrafted animals, human cells could also be demonstrated in the spleen and were found to be of multiple lineages (not shown). In addition, when highly purified $\mathrm{CD} 34^{+} 38^{-}$cells were used, which represent a 10 -fold enriched population of primitive human hematopoietic cells as compared with the total $\mathrm{CD} 4^{+}$population, binding of $\mathrm{CD} 34^{+} 38^{-}$cells to $\mathrm{C}-274$ $(30.1 \pm 3.5 \%$, mean \pm SEM, $n=14)$ was found to be similar $(P=0.99)$ to the binding of $\mathrm{CD} 34^{+}$cells (Fig. $7 A, 30.2 \pm 2.9 \%$, $n=3)$. Furthermore, there was a highly significant linear correlation $(r=0.88, P<0.0001)$ between the number of CD $34^{+} 38^{-}$input cells and number of C-274-adherent cells recovered when measured over a range of input cells from $1 \times$ $10^{4}$ to $24 \times 10^{4}$ cells per dish, suggesting that the binding of these cells to C-274 was direct and not mediated by accessory cells. Finally, expression of RGD-specific integrin $\alpha v \beta 1$ could not be detected on peripheral blood CD $34^{+}$cells (not shown), although we did confirm expression of this receptor on HEL cells, as previously reported (39). Together, these results confirm that VLA-5 is expressed on primitive human hematopoie- 

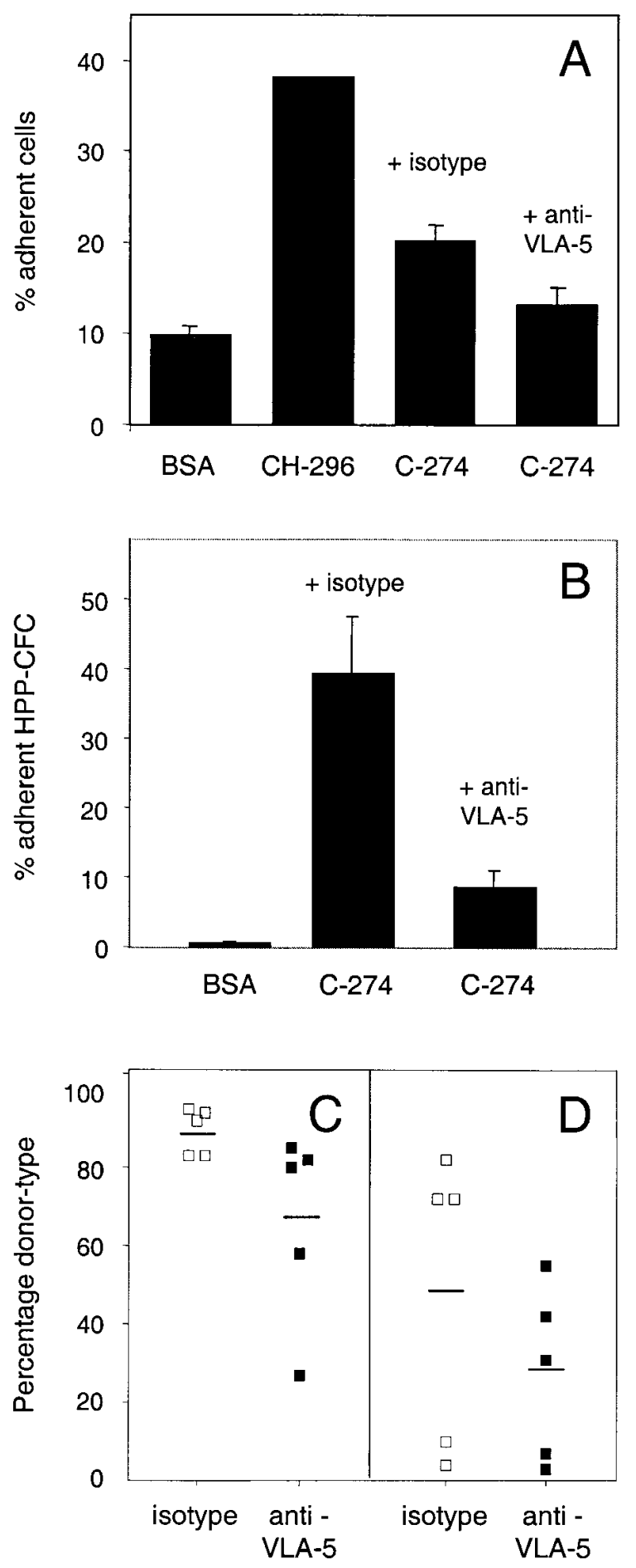

Figure 6. Role of VLA-5 in adhesion of mouse hematopoietic cells to RGD-containing peptide C-274. Low-density mouse hematopoietic cells were preincubated with either anti-mouse VLA-5 or isotype control monoclonal antibody and allowed to adhere to C-274-coated plates in the presence of antibody. Controls include plates coated with BSA and CH-296. Bars indicate mean $( \pm$ SD). $(A)$ Percentage of adherent cells; $(B)$ percentage of adherent HPP-CFC; and $(C$ and $D)$ percentage of donor-type hemoglobin in recipient WBB6F1/J-Kit ${ }^{\mathrm{W}}$ / $\mathrm{Kit}^{\mathrm{W}-\mathrm{V}}$ mice transplanted with C-274-adherent BM cells from

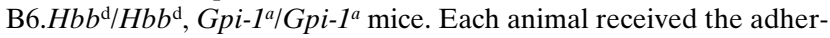
ent fraction of the equivalent of $1 \times 10^{5}(C)$ and $3 \times 10^{4}(D)$ total input low-density cells, respectively. Dots indicate percentage donor-type hemoglobin in individual animals as determined by densitometry; the tic cells and can mediate binding to the CELL-binding domain of extracellular matrix protein FN.

Recombinant peptide $\mathrm{CH}-296$ but not $\mathrm{C}-274$ can interfere with engraftment. Since little data exists that validates in vitro adhesion assays with respect to physiological interactions important in stem cell engraftment in vivo, we used recombinant FN peptides to investigate the potential role of the different FN receptors in reconstitution of BM cells in irradiated recipient animals. Low-density BM cells were preincubated with FN peptides or with blocking anti-VLA-4 or anti-VLA-5 antibodies (or isotype controls) all at a saturating concentration of 100 $\mu \mathrm{g} / \mathrm{mL}$ for $30 \mathrm{~min}$ at $4^{\circ} \mathrm{C}$. Cells were washed once and injected into splenectomized irradiated syngeneic recipients (four animals/group). After $10 \mathrm{~d}$, the number of CFU-C in the BM was enumerated in a progenitor assay. Compared with the BSA or isotype control, the number of CFU-C in groups transplanted with cells preincubated with peptide $\mathrm{CH}-296$ but not C-274 was significantly reduced (Fig. $9 A ; P<0.001$ ). On the other hand, preincubation with integrin VLA-4- and VLA-5-blocking antibodies, either combined (Fig. $9 A ; P<0.001$ ) or used separately (not shown), also reduced the number of CFU-C. These data indicate that the receptors that play a role in the engraftment of hematopoietic cells to the BM of an irradiated recipient could be blocked by a recombinant peptide that contains both the VLA-5- and VLA-4-binding site as well as the high-affinity HEP-binding domain but not by a peptide exclusively containing the RGD site. Not surprisingly, this suggests that the effect of antibodies and peptides on engrafting cells in vivo is more complicated than on adhesion in vitro and implies that engraftment may require the cooperative interaction of multiple adhesion sites and receptors (see below).

Infusion of recombinant fragment $\mathrm{CH}-296$ changes the number of progenitors in the spleen. Since peptide CH-296 inhibited engraftment in vivo of infused cells, we performed a series of experiments to assess the effect of intravenous injection of different recombinant peptides on steady state hematopoiesis. As a control, we examined animals that received a daily injection of recombinant human G-CSF (40). Injection of $\mathrm{CH}$ 296 (ranging from 0.5 to $7.5 \mathrm{mg} / \mathrm{kg} /$ day i.v. for $4 \mathrm{~d}$ ) effected a dose-dependent increase in the number of HPP-CFC in the spleen (Fig. $9 B ; r=0.98, P<0.0001$ ), but not the bone marrow (not shown). At the highest dosage tested, a 6.5-fold increase in splenic HPP-CFC was noted $(P<0.001)$, which is comparable with the ninefold increase found in animals injected with G-CSF (Fig. $9 \mathrm{~B}$ ). When compared with other recombinant FN fragments such as C-274, as is shown in Fig. $9 C$, $\mathrm{CH}-296$ but no other peptides were able to induce a significant increase in splenic HPP-CFC as compared with the BSAinjected animal $(P<0.0001)$. The fold increase between CH-296 and G-CSF treated animals was not significantly different $(P=0.57)$. These results indicate that recombinant FN peptide $\mathrm{CH}-296$ can interfere with steady state hematopoiesis when injected intravenously. In addition, the lack of reactivity or low reactivity of peptides other than peptide $\mathrm{CH}-296$, i.e., peptides containing only two of the three dominant FN-binding domains, suggests that in vivo interactions may be mediated by multiple binding domains, or that the domain structure

horizontal line in each plot indicates the average. The difference in engraftment between control and anti-VLA-5 groups $(C$ and $D)$ was found to be statistically significant (ANOVA; $P=0.0017$ ). 

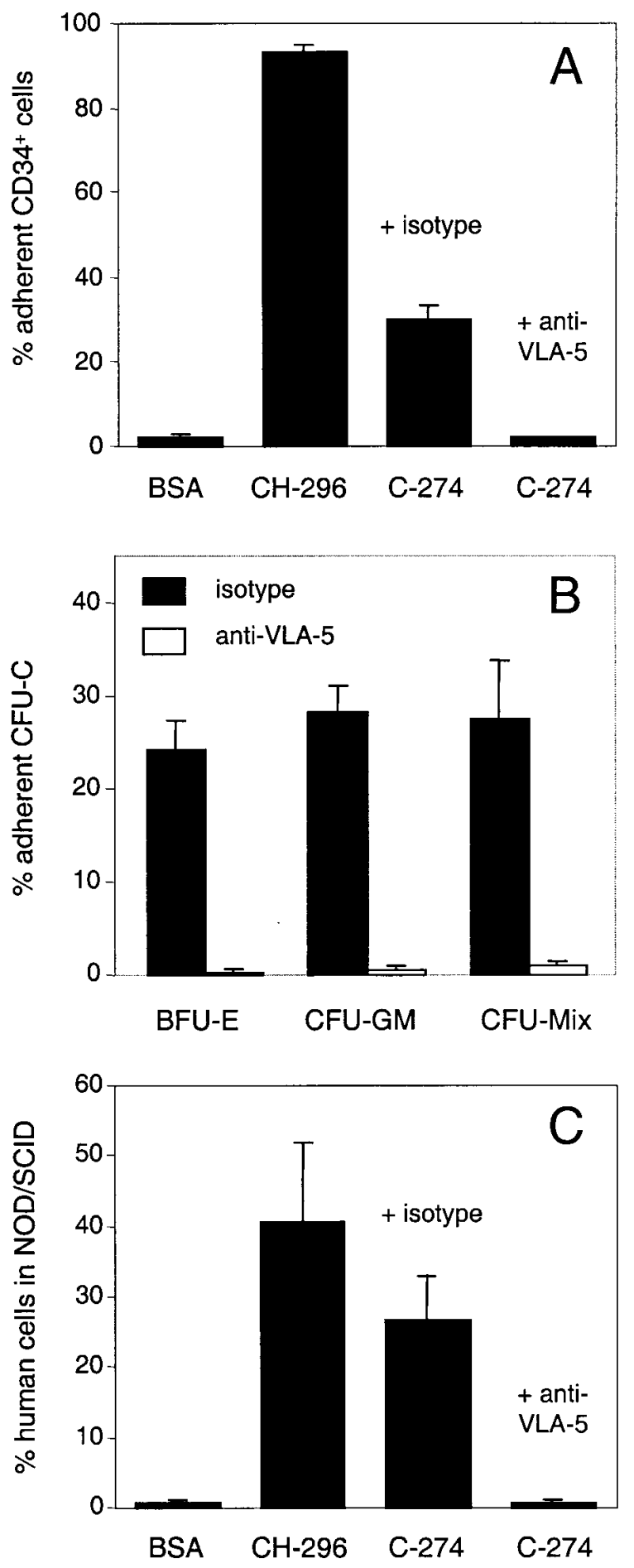

Figure 7. Adherence of human $\mathrm{CD} 34^{+}$peripheral blood progenitor cells and NOD/SCID-repopulating cells to RGD-containing peptide C-274 is mediated by VLA-5. Nontissue culture $10-\mathrm{cm}$ plates were coated with BSA or with peptides C-274 or CH-296 (both at 100 $\mathrm{nmol} / \mathrm{cm}^{2}$ ), as described in detail in Methods. Per plate, a total of 15$20 \times 10^{6}$ human peripheral blood CD34 ${ }^{+}$cells was allowed to adhere, in some groups in the presence of anti-human VLA- 5 or isotype control monoclonal antibody. Adherent cells were collected, tested in progenitor assays, and injected into sublethally irradiated NOD/ SCID mice. $(A)$ Percentage of CD $34^{+}$adherent cells; $(B)$ percentage of adherent BFU-E, CFU-GM, and CFU-Mix; $(C)$ percentage of human cells in the BM of immunodeficient NOD/SCID mice at 2 mo after injection of cells adherent to BSA- or FN-coated plates (BSA
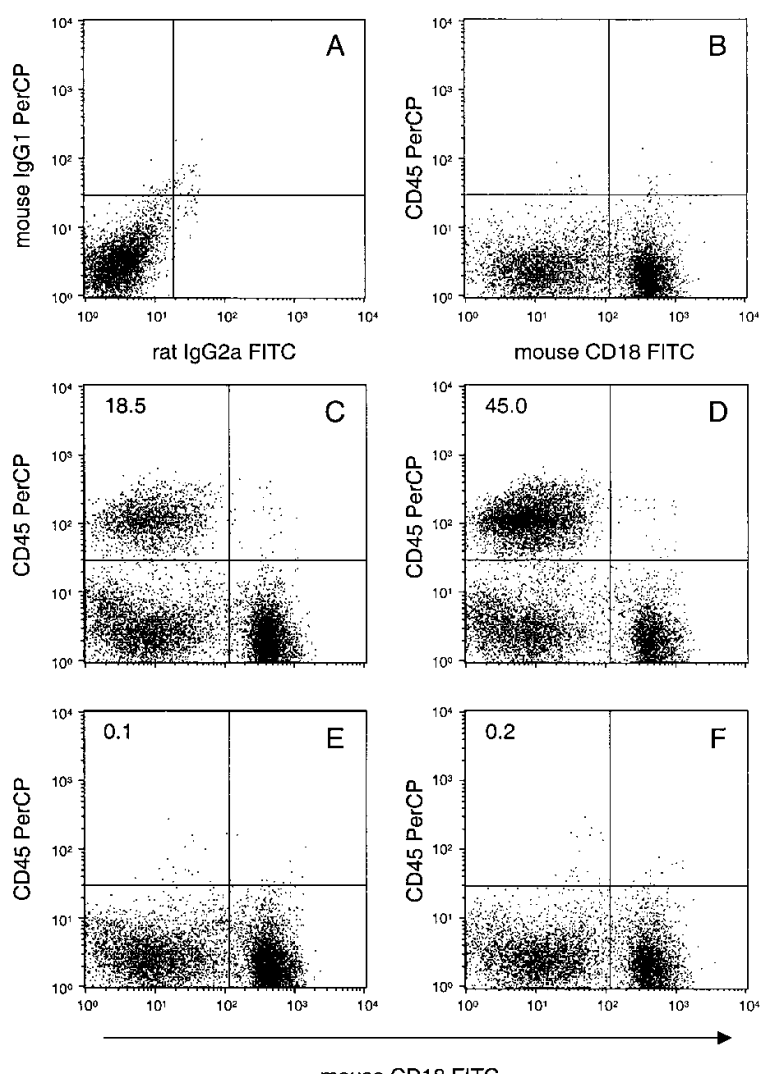

Figure 8. Flow cytometric analysis of transplanted NOD/SCID mice. Flow cytometric analyses of the BM of NOD/SCID nontransplanted control mice or mice transplanted with C-274-adherent human peripheral blood $\mathrm{CD} 34^{+}$cells, at 2 mo after transplantation. $\mathrm{CD} 34^{+}$ cells $\left(20 \times 10^{6}\right.$ cells/plate) were allowed to adhere to C-274 in the presence of anti-human VLA-5 or isotype control monoclonal antibody and adherent and nonadherent cells were collected as described in Methods. ( $A$ and $B$ ) Dot plots of a nontransplanted animal; $(C$ and $D)$ two animals transplanted with isotype control antibody incubated C-274-adherent cells; $(E$ and $F$ ) two animals transplanted with antiVLA-5 incubated C-274-adherent cells. Individual animals received all adherent cells from one plate $(C-F)$. Dot plots show the expression of the human common leukocyte antigen CD45 and mouse antigen $\mathrm{CD} 18$. The percentage of human $\left(\mathrm{CD} 45^{+} \mathrm{mCD} 18^{-}\right)$cells has been indicated.

of soluble FN peptides may differ significantly from plasticabsorbed peptides.

\section{Discussion}

To study the adhesive properties of mouse and human hematopoietic cells, we used plastic-adhered recombinant peptides containing single domains or combinations of the three principle cell-binding domains of human plasma FN $(29,41)$. In agreement with previous studies $(20,27,42,43)$, we demonstrate the presence of both VLA-4 and VLA-5 on human hematopoietic progenitor cells. In addition, using peptide-adhesion assays and anti-VLA-5 blocking antibodies, we provide

group, $n=2$; CH-296 group, $n=5$; C-274 (+isotype antibody) group, $n=5$; C-274 (+ anti-VLA-5 antibody) group, $n=2$ ). Individual animals received all adherent cells from one plate. Bars indicate mean ( \pm SEM). 

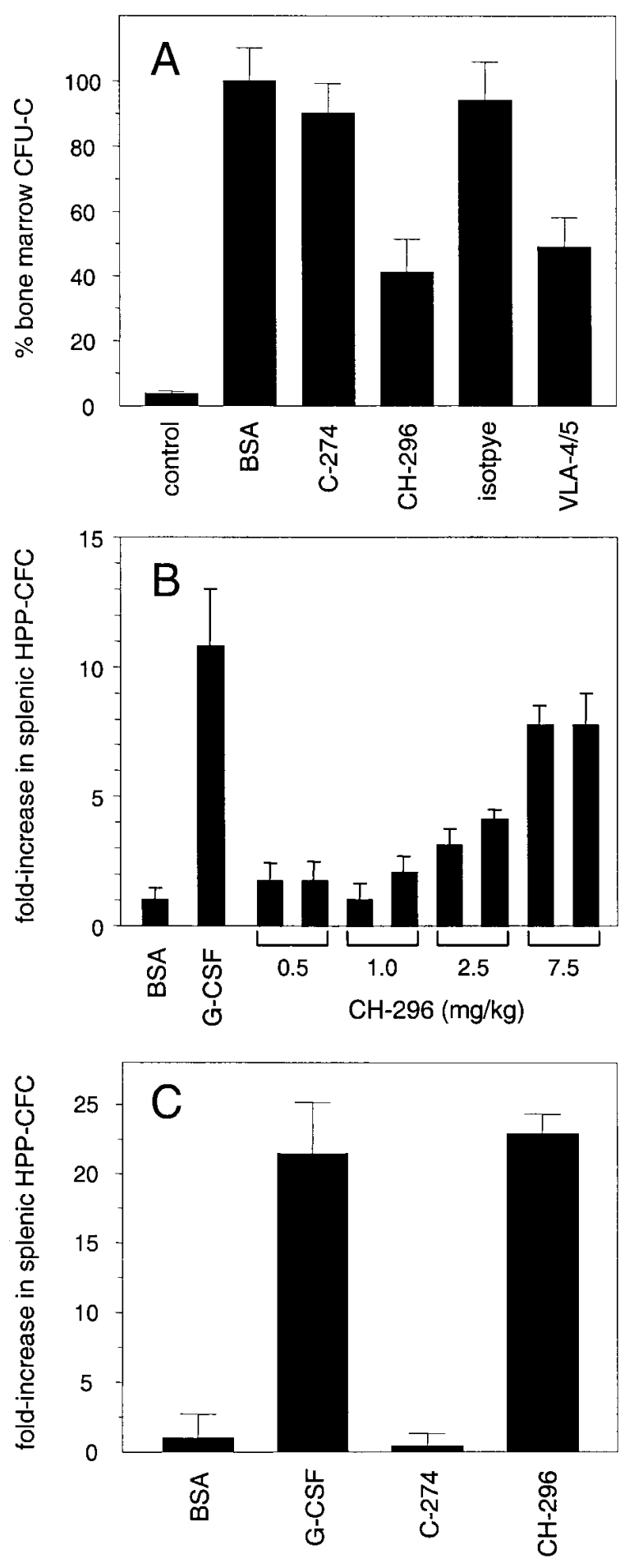

Figure 9. Effect of $\mathrm{FN}$ fragments on engraftment and distribution of hematopoietic cells in vivo. $(A)$ Effect of preincubation of BM cells with recombinant $\mathrm{FN}$ fragments on BM engraftment. Low-density $\mathrm{BM}$ cells were preincubated with FN fragments or monoclonal antibodies (all at a saturating concentration of $0.1 \mathrm{mg} / \mathrm{mL}$ ) for $1 \mathrm{~h}$ at $4^{\circ} \mathrm{C}$ and intravenously injected into splenectomized recipient animals preirradiated with $920 \mathrm{cGy}$ (four animals/group, $4 \times 10^{5}$ cells/animal). After $10 \mathrm{~d}, \mathrm{BM}$ was pooled per group and tested in methylcellulose cultures using triplicate dishes. Bars indicate mean percentage $( \pm \mathrm{SD})$ of BM progenitors relative to the BSA-treated group. $(B)$ Effect of intravenous injection of FN peptide $\mathrm{CH}-296(0.5-7.5 \mathrm{mg} / \mathrm{kg}$ body weight per day for $4 \mathrm{~d})$, human G-CSF ( $250 \mu \mathrm{g} / \mathrm{kg} / \mathrm{day})$, or vehicle (BSA) on the number of HPP-CFC in the spleen (one animal/group). proof of VLA-5 receptors on primitive human hematopoietic cells, as identified by their ability to repopulate NOD/SCID mice with multiple lineages, and on mouse in vivo repopulating stem cells as measured by long-term repopulation in WBB6F1/J-Kit ${ }^{\mathrm{W}} / \mathrm{Kit}^{\mathrm{W}-\mathrm{V}}$ mice. The data complement and extend previous findings of the expression of VLA-5 by primitive in vitro colony-forming cells (cobblestone area-forming cells, day $35 ; 28$ ) and enhanced transfection of mouse HSC on FN fragment $\mathrm{CH}-271$ (6). In apparent contrast with our current observations, others have used adhesion depletion of more mature progenitors on intact plasma $\mathrm{FN}$ as a method to purify hematopoietic stem cells from mouse fetal liver (44). However, it may be difficult to directly compare the binding of cells with intact FN versus enzymatically cleaved or recombinant FN peptides as evidence suggests that the domain structure may differ significantly between these molecules (45). Such differences may also explain the increased adhesion of HSC to the carboxy-terminal FN 30/35 fragment of plasma FN as compared with intact FN (19) and greater transduction efficiency of LTC-IC on FN 30/35 compared with intact FN (4). In addition, in the present study, we have used hematopoietic cells from adult mouse BM, which may differ in their adherent properties from fetal liver hematopoietic cells. Thus, within the hematopoietic microenvironment, not only the level of expression and activation state of integrin receptors on hematopoietic cells, but also the presence of enzymatically modified peptides within the extracellular matrix that present an enhanced but otherwise cryptic domain structure $(45,46)$ may be an important determinant of primitive hematopoietic cell adhesion.

When mouse BM cells were preincubated with FN peptide $\mathrm{CH}-296$, which displayed the highest cell-binding activity of all peptides tested, the engraftment of progenitors into the BM of irradiated splenectomized animals was significantly decreased. This decrease was comparable with that obtained after preincubation with integrin-blocking antibodies. In addition, when peptide $\mathrm{CH}-296$ was intravenously injected, the number of HPP-CFC in the spleen was significantly increased indicating that the peptide disturbed steady state hematopoiesis by changing the distribution of hematopoietic progenitor cells between BM and spleen. This effect was specific for peptide CH-296 and could not be observed with peptides that only contained one or two of the FN cell-binding sites. Supporting these data, others have found that pretreatment of transplanted BM cells or recipients with a synthetic CS1 peptide alone did not change the homing of transplanted CFU-S to the $\mathrm{BM}$ as compared with control nor did it change the number of CFU-C recovered from the $\mathrm{BM}$, spleen, or peripheral blood $(47,48)$. Our data on the effects of peptide $\mathrm{CH}-296$ suggest that there may be a significant additive or cooperative effect between VLA-5, VLA-4, and proteoglycan/CD44 in vivo, which has not previously been described. In addition, it seems clear from these data that interpretation of in vitro adhesion studies, and extrapolation of these results with respect to relationships between BM cells and the microenvironment in vivo, must be done cautiously.

(C) Effect of intravenous injection of peptides C-274 and CH-296 (both at $7.5 \mathrm{mg} / \mathrm{kg} /$ day), human G-CSF $(250 \mu \mathrm{g} / \mathrm{kg} /$ day), or vehicle (BSA) of a representative experiment (one animal/group). The results are expressed as fold increase of HPP-CFC in the spleen relative to the BSA-injected control animal. Bars (in $B$ and $C$ ) indicate average of triplicate cultures \pm SD. 
Integrin VLA-4 and VLA-5 have both been described to play a role in the adhesion and/or migration of cells in other systems. For example, VLA-4 and VLA-5 have been implicated in the migration and differentiation of human thymocytes (24). While VLA-4 by itself was involved in adherence during all stages of differentiation, a coordinated action of both VLA-4 and VLA-5 was required for the persistence and directionality of migration. In addition, studies on neural crest cells, Chinese hamster ovary cells and tumor cells have suggested that VLA-5 may be involved in maintaining the direction of migration of cells, while VLA-4 has been thought to be required for the speed of migration (49-51). In fact, $\beta 1$-integrin-deficient embryonic stem cells have been shown to be defective in migration in vivo but not in their proliferation or differentiation (52). For mast cells it has been shown that the VLA-5-dependent adhesion to immobilized FN could be enhanced by activation of the $c$-kit tyrosine kinase, by either the soluble or membrane-associated form of SCF $(53,54)$. Based on this observation, it has been suggested that the defect seen in migrational lineages in viable $\mathrm{W}$ mutants that express $c$-kit with a nonfunctional kinase domain may be linked to the inability of these cells to activate VLA-5 (53). VLA-4 has also been linked to the $c$-kit pathway by the observation that the anti-VLA-4 induced mobilization of progenitor cells from the $\mathrm{BM}$ into the peripheral blood required a cooperative signal involving c-kit (55). While in BM transplantation VLA-4 has been shown to be important for the initial steps of homing and engraftment (48), VLA-5 may be involved in the migration of HSCs in the BM microenvironment as suggested above or in different aspects of stem cell behavior. In this regard, in vitro assays may not entirely define cell and matrix interactions important for homing and engraftment in vivo, as demonstrated here for VLA-5. Nonetheless, future studies should examine in more detail the potential role(s) of VLA-5 in hematopoietic cell survival, cell cycling, and apoptosis $(9,10,56-58)$ as they may be important for the manipulation of hematopoietic cells ex vivo, especially in retroviral infection protocols that use extracellular matrix proteins such as FN.

\section{Acknowledgments}

The authors thank Dr. Edward F. Srour, Dr. Cristie M. Traycoff, and the members of our lab for critically reviewing the manuscript. Furthermore, we acknowledge Dr. Mervin C. Yoder for the B6.Hbb ${ }^{\mathrm{d}}$ / $H b b^{\mathrm{d}}, G p i-1^{a} / G p i-1^{a}$ mice, Dr. Leonard D. Shultz for providing us with founders to set up a NOD/LtSz-scid/scid breeding colony, Baxter Immunotherapy (Irvine, CA) for providing us with preclinical Isolex $^{\circledR}$ immunomagnetic CD34-selection kits. In addition, we thank Tony Austin for the hemoglobin electrophoresis densitometry.

The Wells Center for Pediatric Research is a Center of Excellence in Molecular Hematology funded by the National Institute of Diabetes and Digestive and Kidney Diseases (P50 DK 49218), which supports the NOD/SCID colony.

\section{References}

1. Dexter, T.M., T.D. Allen, and L.G. Lajhta. 1977. Conditions controlling the proliferation of haemopoietic stem cells in vitro. J. Cell Physiol. 91:335-344.

2. Ruoslahti, E. 1988. Fibronectin and its receptors. Annu. Rev. Biochem. 57:375-413.

3. Hynes, R.O. 1990. Fibronectins. Springer Series in Molecular Biology. A. Rich, editor. Springer Verlag, New York.

4. Moritz, T., V.P. Patel, and D.A. Williams. 1994. Bone marrow extracellular matrix molecules improve gene transfer into human hematopoietic cells via retroviral vectors. J. Clin. Invest. 93:1451-1457.

5. Moritz, T., P. Dutt, X. Xiao, D. Carstanjen, T. Vik, H. Hanenberg, and D.A. Williams. 1996. Fibronectin improves transduction of reconstituting hematopoietic stem cells by retroviral vectors: evidence of direct viral binding to chymotryptic carboxy-terminal fragments. Blood. 88:855-862.

6. Hanenberg, H., X.L. Xiao, D. Dilloo, K. Hashino, I. Kato, and D.A. Williams. 1996. Colocalization of retrovirus and target cells on specific fibronectin fragments increases genetic transduction of mammalian cells. Nat. Med. 2:876882 .

7. Meredith, J.E., B. Fazeli, and M.A. Schwartz. 1993. The extracellular matrix as a cell survival factor. Mol. Biol. Cell. 4:953-961.

8. Schwartz, M.A., C. Lechene, and D.E. Ingber. 1991. Insoluble fibronectin activates the $\mathrm{Na} / \mathrm{H}$ antiporter by clustering and immobilizing integrin alpha 5 beta 1, independent of cell shape. Proc. Natl. Acad. Sci. USA. 88:7849-7853.

9. Zhang, Z., K. Vuori, J.C. Reed, and E. Ruoslahti. 1995. The alpha 5 beta 1 integrin supports survival of cells on fibronectin and up-regulates Bcl-2 expression. Proc. Natl. Acad. Sci. USA. 92:6161-6165.

10. O'Brien, V., S.M. Frisch, and R.L. Juliano. 1996. Expression of the integrin alpha 5 subunit in HT29 colon carcinoma cells suppresses apoptosis triggered by serum deprivation. Exp. Cell Res. 224:208-213.

11. Pierschbacher, M.D., and E. Ruoslahti. 1984. Cell attachment activity of fibronectin can be duplicated by small synthetic fragments of the molecule. $\mathrm{Na}$ ture. 309:30-33.

12. Aota, S., M. Nomizu, and K.M. Yamada. 1994. The short amino acid sequence Pro-His-Ser-Arg-Asn in human fibronectin enhances cell-adhesive function. J. Biol. Chem. 269:24756-24761.

13. Danen, E.H.J., S. Aota, A.A. van Kraats, K.M. Yamada, D.J. Ruiter, and G.N.P. van Muijen. 1995. Requirement for the synergy site for cell adhesion to fibronectin depends on the activation state of integrin alpha 5 beta 1.J. Biol. Chem. 270:21612-21618.

14. Leahy, D.J., I. Aukhil, and H.P. Erickson. 1996. 2.0 A crystal structure of a four-domain segment of human fibronectin encompassing the RGD loop and synergy region. Cell. 84:155-164.

15. Humphries, M.J., A. Komoriya, S.K. Akiyama, K. Olden, and K.M. Yamada. 1987. Identification of two distinct regions of the type III connecting segment of human plasma fibronectin that promote cell type-specific adhesion. $J$. Biol. Chem. 262:6886-6892.

16. Mohri, H., K. Katoh, A. Iwamatsu, and T. Okubo. 1996. The novel recognition site in the C-terminal heparin-binding domain of fibronectin by integrin alpha 4 beta 1 receptor on HL-60 cells. Exp. Cell Res. 222:326-332.

17. Mould, A.P., A. Komoriya, K.M. Yamada, and M.J. Humphries. 1991. The CS5 peptide is a second site in the IIICS region of fibronectin recognized by the integrin alpha 4 beta 1 . Inhibition of alpha 4 beta 1 function by RGD peptide homologues. J. Biol. Chem. 266:3579-3585.

18. Ruoslahti, E. 1996. RGD and other recognition sequences for integrins. Ann. Rev. Cell Dev. Biol. 12:697-715.

19. Williams, D.A., M. Rios, C. Stephens, and V.P. Patel. 1991. Fibronectin and VLA-4 in haematopoietic stem cell-microenvironment interactions. $\mathrm{Na}$ ture. 352:438-441.

20. Verfaillie, C.M., J.B. McCarthy, and P.B. McGlave. 1991. Differentiation of primitive human multipotent hematopoietic progenitors into single lineage clonogenic progenitors is accompanied by alterations in their interaction with fibronectin. J. Exp. Med. 174:693-703.

21. Papayannopoulou, T., and B. Nakamoto. 1993. Peripheralization of hemopoietic progenitors in primates treated with anti-VLA4 integrin. Proc. Natl. Acad. Sci. USA. 90:9374-9378.

22. Papayannopoulou, T., C. Craddock, B. Nakamoto, G.V. Priestley, and N.S. Wolf. 1995. The VLA4/VCAM-1 adhesion pathway defines contrasting mechanisms of lodgement of transplanted murine hemopoietic progenitors between bone marrow and spleen. Proc. Natl. Acad. Sci. USA. 92:9647-9651.

23. Mojcik, C.F., D.R. Salomon, A.C. Chang, and E.M. Shevach. 1995. Differential expression of integrins on human thymocyte subpopulations. Blood. 86:4206-4217.

24. Crisa, L., V. Cirulli, M.H. Ellisman, J.K. Ishii, M.J. Elices, and D.R. Salomon. 1996. Cell adhesion and migration are regulated at distinct stages of thymic T cell development: the roles of fibronectin, VLA4, and VLA5. J. Exp. Med. 184:215-228.

25. Patel, V.P., and H.F. Lodish. 1984. Loss of adhesion of murine erythroleukemia cells to fibronectin during erythroid differentiation. Science. 224:996998.

26. Vuillet Gaugler, M.H., J. Breton Gorius, W. Vainchenker, J. Guichard, C. Leroy, G. Tchernia, and L. Coulombel. 1990. Loss of attachment to fibronectin with terminal human erythroid differentiation. Blood. 75:865-873.

27. Kerst, J.M., J.B. Sanders, I.C. Slaper-Cortenbach, M.C. Doorakkers, B. Hooibrink, R.H. van Oers, A.E. von dem Borne, and C.E. van der Schoot. 1993. Alpha 4 beta 1 and alpha 5 beta 1 are differentially expressed during myelopoiesis and mediate the adherence of human CD34+ cells to fibronectin in an activation-dependent way. Blood. 81:344-351.

28. van der Sluijs, J.P., M.R. Baert, and R.E. Ploemacher. 1994. Differential adherence of murine hematopoietic stem cell subsets to fibronectin. Exp. Hematol. 22:1236-1243.

29. Kimizuka, F., Y. Taguchi, Y. Ohdate, Y. Kawase, T. Shimojo, K. Hashino, 
I. Kato, K. Sekiguchi, and K. Titani. 1991. Production and characterization of functional domains of human fibronectin expressed in Escherichia coli. J. Biochem. 110:284-291.

30. Shultz, L.D., P.A. Schweitzer, S.W. Christianson, B. Gott, I.B. Schweitzer, B. Tennent, S. McKenna, L. Mobraaten, T.V. Rajan, D.L. Greiner, et al. 1995. Multiple defects in innate and adaptive immunologic function in NOD/ LtSz-scid mice. J. Immunol. 154:180-191.

31. Katayama, M., F. Hino, Y. Ohdate, S. Goto, F. Kimizuka, I. Kato, K. Titani, and K. Sekiguchi. 1989. Isolation and characterization of two monoclonal antibodies that recognize remote epitopes on the cell-binding domain of human fibronectin. Exp. Cell Res. 185:229-236.

32. Moore, G.E., A.A. Sandberg, and K. Ulrich. 1966. Suspension cell culture and in vivo and in vitro chromosome constitution of mouse leukemia L1210. J. Natl. Cancer Inst. 36:405-421.

33. Ichikawa, Y. 1969. Differentiation of a cell line of myeloid leukemia. J. Cell. Physiol. 74:223-234.

34. Martin, P., and T. Papayannopoulou. 1982. HEL cells: a new human erythroleukemia cell line with spontaneous and induced globin expression. Science. 216:1233-1235.

35. Bradley, T.R., and G.S. Hodgson. 1979. Detection of primitive macrophage progenitor cells in mouse bone marrow. Blood. 54:1446-1450.

36. Whitney, J.B.I. 1978. Simplified typing of mouse hemoglobin (Hbb) phenotypes using cystamine. Biochem. Genet. 16:667-672.

37. Hodgson, G.S., T.R. Bradley, and J.M. Radley. 1982. The organization of hemopoietic tissue as inferred from the effects of 5-fluorouracil. Exp. Hematol. 10:26-35

38. van der Loo, J.C.M., H. Hanenberg, R.J. Cooper, F.-Y. Luo, E.N. Lazaridis, and D.A. Williams. 1998. NOD/SCID mouse as a model system to study the engraftment and mobilization of human peripheral blood stem cells. Blood. In press.

39. Molla, A., R. Berthier, A. Chapel, A. Schweitzer, and A. Andrieux. 1995. Beta 1 integrins mediate adherent phenotype of human erythroblastic cell lines after phorbol 12-myristate 13-acetate induction. Biochem. J. 309:491-497.

40. Neben, S., K. Marcus, and P. Mauch. 1993. Mobilization of hematopoietic stem and progenitor cell subpopulations from the marrow to the blood of mice following cyclophosphamide and/or granulocyte colony-stimulating factor. Blood. 81:1960-1967.

41. Hashino, K., Y. Uemori, F. Kimizuka, I. Kato, and K. Titani. 1996. A 31$\mathrm{kDa}$ recombinant fibronectin cell-binding domain fragment: Its binding to receptor, cell adhesive activity, and fusion proteins. J. Biochem. 119:604-609.

42. Liesveld, J.L., J.M. Winslow, K.E. Frediani, D.H. Ryan, and C.N. Abboud. 1993. Expression of integrins and examination of their adhesive function in normal and leukemic hematopoietic cells. Blood. 81:112-121.

43. Teixidó, J., M.E. Hemler, J.S. Greenberger, and P. Anklesaria. 1992. Role of beta 1 and beta 2 integrins in the adhesion of human CD34 $4^{\text {hi }}$ stem cells to bone marrow stroma. J. Clin. Invest. 90:358-367.

44. Jordan, C.T., J.P. McKearn, and I.R. Lemischka. 1990. Cellular and de- velopmental properties of fetal hematopoietic stem cells. Cell. 61:953-963.

45. Ugarova, T.P., A.V. Ljubimov, L. Deng, and E.F. Plow. 1996. Proteolysis regulates exposure of the IIICS-1 adhesive sequence in plasma fibronectin. Biochemistry. 35:10913-10921.

46. Morla, A., Z. Zhang, and E. Ruoslahti. 1994. Superfibronectin is a functionally distinct form of fibronectin. Nature. 367:193-196.

47. Craddock, C.F., B. Nakamoto, M. Elices, and T. Papayannopoulou. 1997. The role of CS1 moiety of fibronectin in VLA mediated haemopoietic progenitor trafficking. Br. J. Haematol. 97:15-21.

48. Papayannopoulou, T., and C. Craddock. 1997. Homing and trafficking of hemopoietic progenitor cells. Acta Haematol. 97:97-104.

49. Dufour, S., J.L. Duband, M.J. Humphries, M. Obara, K.M. Yamada, and J.P. Thiery. 1988. Attachment, spreading and locomotion of avian neura crest cells are mediated by multiple adhesion sites on fibronectin molecules. EMBO J. 7:2661-2671.

50. Bauer, J.S., C.L. Schreiner, F.G. Giancotti, E. Ruoslahti, and R.L. Juliano. 1992. Motility of fibronectin receptor-deficient cells on fibronectin and vitronectin: collaborative interactions among integrins. J. Cell Biol. 116:P477P487.

51. Beauvais, A., C.A. Erickson, T. Goins, S.E. Craig, M.J. Humphries, J.P Thiery, and S. Dufour. 1995. Changes in the fibronectin-specific integrin expression pattern modify the migratory behavior of sarcoma S180 cells in vitro and in the embryonic environment. J. Cell Biol. 128:699-713.

52. Hirsch, E., A. Iglesias, A.J. Potocnik, U. Hartmann, and R. Fassler. 1996. Impaired migration but not differentiation of haematopoietic stem cells in the absence of beta1 integrins. Nature. 380:171-175.

53. Kinashi, T., and T.A. Springer. 1994. Steel factor and $c$-kit regulate cellmatrix adhesion. Blood. 83:1033-1038.

54. Takahira, H., A. Gotoh, A. Ritchie, and H.E. Broxmeyer. 1997. Steel factor enhances integrin-mediated tyrosine phosphorylation of focal adhesion kinase (pp125FAK) and paxillin. Blood. 89:1574-1584.

55. Papayannopoulou, T., G.V. Priestly, and B. Nakamoto. 1998. AntiVLA4/VCAM-1-induced mobilization requires cooperative signaling through the kit/mkit pathway. Blood. 91:2231-2239.

56. Gong, J., T.C. Ko, and M.G. Brattain. 1998. Disruption of fibronectin binding to the alpha 5 beta 1 integrin stimulates the expression of cyclin-dependent kinases and DNA synthesis through activation of extracellular signal-regulated kinase. J. Biol. Chem. 273:1662-1669.

57. Sugahara, H., Y. Kanakura, T. Furitsu, K. Ishihara, K. Oritani, H. Ikeda, H. Kitayama, J. Ishikawa, K. Hashimoto, Y. Kanayama, et al. 1994. Induction of programmed cell death in human hematopoietic cell lines by fibronectin via its interaction with very late antigen 5. J. Exp. Med. 179:1757-1766.

58. Terui, Y., Y. Furukawa, T. Sakai, J. Kikuchi, H. Sugahara, Y. Kanakura, S. Kitagawa, and Y. Miura. 1996. Up-regulation of VLA-5 expression during monocytic differentiation and its role in negative control of the survival of peripheral blood monocytes. J. Immunol. 156:1981-1988. 